\title{
Padatan Tersuspensi yang Dipengaruh oleh Proses Pasang Surut di Perairan Kaliboyo, Kabupaten Pekalongan
}

\author{
Anugrah Riskel Shabari, Alfi Satriadi, Warsito Atmodjo \\ Departemen Oseanografi, Fakultas Perikanan dan IImu Kelautan, Universitas Diponegoro \\ JI. Prof. H. Sudarto, SH, Tembalang Semarang. 50275 Indonesia \\ *Corresponding author, e-mail: anugrahriskelshabari@gmail.com
}

\begin{abstract}
ABSTRAK: Perairan Kaliboyo merupakan daerah yang berpotensi mengalami pendangkalan akibat pengendapan sedimen tersuspensi. Potensi dari pengdangkalan tersebut dapat diketahui dengan mengetahui nilai konsentrasi dan sebaran Material Padatan Tersuspensi (MPT). Konsentrasi MPT yang tinggi di laut dipengaruhi oleh arus yang dibangkitkan oleh pasang surut. Tujuan dilakukannya penelitian ini adalah untuk mengetahui pengaruh arus laut terhadap konsentrasi dan sebaran MPT di Perairan Kaliboyo Kabupaten Batang, Jawa Tengah. Materi yang digunakan meliputi utama berupa data sampel air dan arus laut sedangkan data pendukung berupa data pasang surut BMKG, dan debit sungai PSDA Jawa Tengah tahun 2017, bathimetri hasil pemeruman tanggal 15 September 2018, dan peta RBI 2017. Penelitian ini menggunakan metode kuantitatif yang bersifat eksploratif, penentuan lokasi pengambilan sampel air menggunakan metode purposive sampling, pengambilan data arus laut menggunakan metode lagrange. Model matematik yang digunakan adalah Flow Flexible Mesh Model 2D untuk arah pergerakan arus dan Inverse Distance Weighted untuk interpolasi sebaran MPT. Berdasarkan hasil dari penelitian menunjukkan bahwa nilai material padatan tersuspensi pasang menuju surut pada kedalaman $0.2 \mathrm{~d}$ memiliki nilai antara $0,027 \mathrm{~g} / \mathrm{l}-0.114 \mathrm{~g} / \mathrm{l}$, kedalaman $0.6 \mathrm{~d}$ memiliki nilai antara $0,030 \mathrm{~g} / \mathrm{l}-0,114 \mathrm{~g} / \mathrm{l}$, dan kedalaman $0.8 \mathrm{~d}$ memiliki nilai antara 0,038 g/l - 0,118 $\mathrm{g} / \mathrm{l}$. Kecepatan arus memiliki nilai antara $0.0181 \mathrm{~m} / \mathrm{dt}-0.2011 \mathrm{~m} / \mathrm{dt}$ dengan arah dominan $\mathrm{ke}$ arah barat laut. Berdasarkan hasil penelitian dapat disimpulkan bahwa konsentrasi tertinggi material padatan tersuspensi berada di muara sungai dan daerah yang masih dipengaruhi oleh sungai dan mengecil menuju laut lepas.
\end{abstract}

Kata Kunci: Material Padatan Tersuspensi, Arus, Pasang surut.

\section{Suspended Solids Distribution Material Due to Tidal Flow at the Kaliboyo River Estuary, Batang}

ABSTRACT: Kaliboyo River is an area that has potential by silting due to the deposition of suspended sediments. The potential of this silting can be known by understanding the value of concentration and the distribution of suspended sediment load. The high suspended sediment load concentration in the ocean is influenced by currents generated by tides. The purpose of this research the effect of ocean currents on the concentration and distribution of suspended sediment load in the Kaliboyo River of Batang Regency, Central Java. The material used includes the main data such as water sample, and current. while the supporting data consists of tides data from BMKG, and river discharge from Central Java PSDA in 2017, bathimetry results from September 15, 2018, and RBI 2017 map This study uses quantitative methods that are explorative in nature, taking the location of sampling using the purposive sampling method, taking ocean currents using the lagrange method. The mathematical model used is 2D Flow Flexible Mesh Model for flow direction and Inverse Distance Weighted for TSS distribution interpolation. Based on the results of the study, it was found that the value of the tide suspended solids to tide at the $0.2 d$ level had a value between $0.027 \mathrm{~g} / \mathrm{I}-0.114 \mathrm{~g} / \mathrm{I}, 0.6 \mathrm{~d}$ depth had a value between $0.030 \mathrm{~g} / \mathrm{I}-0.114 \mathrm{~g} / \mathrm{l}$, and $0.8 d$ has a value between $0.038 \mathrm{~g} / \mathrm{I}-0.118 \mathrm{~g} / \mathrm{l}$. The current velocity has a value between 0.0181 $\mathrm{m} / \mathrm{dt}-0.2011 \mathrm{~m} / \mathrm{dt}$ with the dominant direction to the northwest. Based on the results of the study it can be concluded that the highest concentration of total suspended solid in the estuary of the river and the area where still influeced by the river and shrinking towards the open sea.

Keywords: Suspended Sediment Load, Currents, Tides. 


\section{PENDAHULUAN}

Menurut Qhomariyah dan Yuwono (2016), arus pasang surut disebabkan oleh fenomena pasang surut yang dapat berubah sesuai dengan tipe dari pasang surut tersebut, sehingga arus pasang surut dapat memiliki tipe seperti tipe pasang surut yaitu diurnal atau harian tunggal dimana dalam satu hari terdapat satu kali perubahan arus, sedangkan untuk daerah yang memiliki tipe pasang surut semi diurnal atau harian ganda maka dalam satu hari akan mengalami dua kali perubahan arah arus. Arus pada sungai dan daerah perairan yang semi tertutup (estuari) lebih dominan di timbulkan oleh faktor pasang surut. Pergerakan sedimen dipengaruhi oleh kecepatan arus dan ukuran butiran sedimen. Semakin besar ukuran butiran sedimen tersebut maka kecepatan arus yang dibutuhkan juga akan semakin besar untuk mengangkut partikel sedimen tersebut.

Pasang surut akan menyebabkan terbawanya material yang akan mengendap di suatu perairan yang kemudian dinamakan sedimentasi, dan saat surut material maka akan mengakibatkan material yang terendapkan terkikis dari dasar perairan. Berdasarkan fenomena pasang surut dapat ditentukan sedimentasi yang terjadi di dermaga untuk menjamin keamanan kapal saat bersandar di dermaga. Jumlah sedimentasi disetiap tempat berbeda-beda, hal ini dikarenakan perbedaan dari pengaruh pasang surut yang terjadi di perairan tersebut (tipe pasang surut) dan respon yang dilakukan oleh tempat terbentuknya sedimentasi disamping pengaruh yang disebabkan oleh ombak dan angin (Qhomariyah dan Yuwono, 2016).

Materi padatan tersuspensi (MPT) merupakan partikel-partikel yang melayang dalam kolom perairan, yang terdiri dari komponen organik (hidup) dan anorganik (mati). Komponen organik (hidup) terdiri dari fitoplankton, bakteri, jamur, dan lain-lain. Sedangkan pada komponen anorganik (mati) terdiri dari detritus dan partikel - partikel komponen anorganik (mati) lainnya (Hutagalung et al., 1997 dalam Satriadi dan Widada, 2004). Partikel padatan tersuspensi ini kemudian dapat diklasifikasikan menjadi zat padat terapung yang selalu bersifat organik (hidup) dan zat padat terendap yang dapat bersifat organik (hidup) dan anorganik (mati). Kemudian Alaerts dan Santika (1987) menjelaskan bahwa keberadaan materi padatan tersuspensi (MPT) di perairan dapat berupa pasir, lumpur, tanah liat, koloid, serta bahan bahan organik seperti plankton dan organisme lain.

Menurut Mulyanto (2007) sungai memiliki fungsi utama yaitu mengalirkan air dan mengangkut material sedimen hasil erosi pada daerah aliran sungai (DAS) dan alurnya. Material sedimen ini sebagian akan terbawa air banjir ke luar alur aliran untuk kemudian diendapkan dan sebagian besar lainnya akan terbawa sampai ke laut atau muara sungai. Berdasarkan hal tersebut maka muara sungai berfungsi sebagai pengeluaran atau pembuangan debit sungai terutama pada saat banjir ke laut. Selain itu, muara sungai mempunyai nilai ekonomis yang penting karena dapat berfungsi sebagai alur penghubung antara laut dengan daerah yang cukup dalam di daratan. Permasalahan yang sering dihadapi adalah adanya sedimentasi dan abrasi di sekitar muara yang dapat mempengaruhi kualitas perairan sekitarnya. Demikian juga di muara sungai Kaliboyo tepatnya di desa Roban kabupaten Batang terjadi sedimentasi di sekitar muara sungai yang ditandai dengan berkurangnya kedalaman dan menyempitnya lebar muara sungai. Perairan muara sungai Kaliboyo merupakan daerah tangkapan ikan, tambak, dan terdapat pelabuhan pendaratan ikan yang berfungsi sebagai tempat penjualan ikan. Dengan adanya sedimentasi dan abrasi maka dapat menurunkan kondisi ekonomi penduduk disekitar pantai Gebang. Sedimen tersuspensi merupakan sedimen yang berbentuk kecil yang melayang di kolom air dan pada saat tertentu dapat mengendap di dasar perairan sehingga berpengaruh terhadap sedimentasi.

Muara sungai Kaliboyo merupakan daerah tangkapan ikan, tambak, pelabuhan pendaratan ikan dan terdapat aktivitas pembangunan PLTU sehingga hal tersebut akan menyebabkan peningkatan konsentrasi material padatan tersuspensi (MPT). Menurut Rifardi (2012) mengatakan bahwa peningkatan konsentrasi material padatan tersuspensi akan menyebabkan terjadinya kekeruhan yang dapat menggangu penetrasi cahaya masuk ke dalam perairan, pendangkalan dan punahnya atau terganggunya beberapa ekosistem perairan dan kerusakan lingkungan.

Arus pasang surut adalah arus yang bergerak berlawanan arah (bi-directional) pada dasar perairan saat kondisi pasang dan surut. Pada daerah dimana arus arus pasang surut cukup kuat, tarikan gesekan pada dasar laut akan menghasilkan potongan arus secara vertikal dan resultan turbulensi sehingga menyebabkan bercampurnya arus lapisan bawah secara vertikal. Arus pasang 
surut akan menyebabkan terbawanya material yang akan mengendap di suatu perairan yang kemudian dinamakan sedimentasi, dan saat surut material maka akan mengakibatkan material yang terendapkan terkikis dari dasar perairan. Berdasarkan permasalahan diperoleh, maka perlu dilakukan dan dikembangkan penelitian lebih lanjut sehingga penelitian ini bertujuan untuk mengetahui nilai dan pengaruh arus pasang surut terhadap persebaran material padatan tersuspensi di Muara Sungai Kaliboyo, Batang, Jawa Tengah.

\section{MATERI DAN METODE}

Materi yang digunakan pada penelitian ini meliputi data utama dan data penunjang. Data utama yaitu data sampel air dan arus lapangan di Perairan Kaliboyo. Sedangkan data penunjang berfungsi sebagai pendukung data utama dalam pengolahan data agar data yang dihasilkan lebih akurat.

Metode penelitian yang digunakan adalah metode ekploratif. Penelitian Eksploratif merupakan studi dengan melakukan penelusuran, terutama dalam pemantapan konsep yang akan digunakan dalam ruang lingkup yang penelitian yang lebih luas (Yusuf, 2017). Dalam melakukan eksplorasi, konsep yang matang menjadi goal dalam melakukan penelitian. Penelitian eksploratif merupakan penelitian awal yang bertujuan untuk mendapatkan gambaran mengenai suatu topik penelitian yang akan diteliti lebih jauh (Morissan, 2017). Metode penentuan titik sampling ini menggunakan purposive sampling methode. Penentuan lokasi pengambilan sampel penelitian dilakukan berdasarkan kondisi yang diharapkan dapat mewakili kondisi secara keseluruhan daerah yang diteliti.

\section{Metode Analisa Data MPT}

Analisa sedimen tersuspensi menggunakan metode analisa MPT (Alaerts dan Santika, 1987 dalam Satriadi dan Sugeng, 2004) dengan tata cara yang pertama kertas saring whatman dengan ukuran pori $<0,45 \mu \mathrm{m}$ dikeringkan dengan menggunakan oven selama 10 menit dengan suhu kurang lebih $100^{\circ} \mathrm{C}$, kemudian timbang berat kertas saring yang sudah dikeringkan, selanjutnya saring sampel air yang sudah dikocok sebanyak $100 \mathrm{ml}$ ke dalam alat penyaringan yang telah dilapisi kertas saring Whatman ukuran pori $0.45 \mu \mathrm{m}$, setelah itu ambil kertas saring dari alat penyaringan untuk kemudian dikeringkan ke dalam oven dengan suhu $\pm 105^{\circ} \mathrm{C}$ selama 1 jam, kemudian disukkan kertas saring ke dalam desikator, ditimbang kembali berta kertas saring yang sudah terdapat konsentrasi sedimen tersuspensi dan nilai konsentrasi MPT dengan menggunakan rumus

$$
M P T=\frac{(a-b) \text { gram }}{c \text { liter }}
$$

Keterangan : $a=$ berat kertas saring dan berat MPT yang berada di kertas saring $(\mathrm{g}) ; \mathrm{b}=\mathrm{berat}$ kertas saring $(\mathrm{g}) ; \mathrm{c}=$ volume sampel air $(\mathrm{L})$

Verifikasi digunakan untuk membandingkan data pengukuran arus lapangan dengan hasil simulasi model arus. Verivikasi dilakukan dengan menghitung besar kesalahan yang terjadi dari setiap data menggunakan uji statistik maupun perhitungan. Menurut George et al, (2010), besarnya kesalahan dihitung dengan menggunakan nilai CF (Cost Function). CF merupakan nilai non-dimensional yang menghitung perbedaan antara nilai-nilai model dengan data pengukuran lapangan menunjukkan kecocokan antara dua kumpulan data. Kriteria kelayakan nilai model jika $\mathrm{CF}<1$ sangat baik, 1-2 baik, 2-3 wajar, $>3$ jelek. Perhitungan CF (Cost Function) sebagai berikut :

$$
C F=\frac{1}{N} \sum_{n=1}^{N} \frac{\left[D_{n}-M_{n}\right]}{\sigma_{\rho}}
$$

Keterangan : $N=$ Jumlah data pengamatan; $n$ : Nilai ke $n$, dengan $n=1,2,3 \ldots \ldots ; D$ : Nilai pengamatan; M : Nilai model; $\sigma$ : Standar deviasi; D : Rata - rata data pengamatan 
Data pasang surut dianalisis dengan metode admiralty untuk mendapatkan konstanta harmonik pasang surut. Konstanta yang dihasilkan dapat digunakan untuk mengetahui tipe pasang surut dengan menggunakan formula Formzahl. Penentuan tipe pasang surut dilakukan dengan melihat nilai Formzahl (Fadilah et al., 2014). Fomula penentuan tipe pasang surut sebagai berikut:

$$
F=\frac{K 1+O 1}{M 2+S 2}
$$

Berdasarkan nilai Formzahl tersebut, tipe pasang surut diklasifikaskani kedalam :0<F<0,25 = pasut harian Ganda Murni; 0,25<F $<1,50=$ Pasut Campuran Condong Harian Ganda; 1,50< F<3,0 = Pasut Campuran Condong Harian Tunggal; F>3,0 = Pasut Harian Tunggal Murni

\section{HASIL DAN PEMBAHASAN}

Berdasarkan pengolahan data didapatkan nilai komponen-komponen pasang surut yaitu S0 sebesar $60 \mathrm{~cm}$, M2 sebesar $15 \mathrm{~cm}$, S2 $8 \mathrm{~cm}$, N2 sebesar $4 \mathrm{~cm}$, K1 sebesar $18 \mathrm{~cm}$, K2 sebesar 2 $\mathrm{cm}$, O1 sebesar $4 \mathrm{~cm}$, P1 sebesar $6 \mathrm{~cm}$, M4 sebesar $1 \mathrm{~cm}$, dan MS4 sebesar seperti yang disajikan pada Tabel 1.

Berdasarkan Tabel 1. maka diperoleh nilai MSL (Mean Sea Level) sebesar $62 \mathrm{~cm}$, HHWL (Highest High Water Level) sebesar $126 \mathrm{~cm}$, MHWL (Mean High Water Level) sebesar $89 \mathrm{~cm}$, LLWL (Lowest Low Water Level) sebesar $13 \mathrm{~cm}$, MLWL (Mean High Water Level), dan nilai Formzhal $(F=0.9)$ sebesar $39 \mathrm{~cm}$ yang selanjutnya tersaji pada Tabel 2.

Tabel 1. Nilai Amplitudo (A) Pasang Surut Perairan Kaliboyo

\begin{tabular}{ccccccccccc}
\hline & $\mathrm{S} 0$ & $\mathrm{O} 1$ & $\mathrm{P} 1$ & $\mathrm{~K} 1$ & $\mathrm{M} 2$ & $\mathrm{~S} 2$ & $\mathrm{~N} 2$ & $\mathrm{~K} 2$ & $\mathrm{M} 4$ & $\mathrm{MS} 4$ \\
\hline $\mathrm{A}(\mathrm{cm})$ & 60 & 4 & 6 & 18 & 15 & 8 & 4 & 2 & 1 & 1 \\
\hline
\end{tabular}

Tabel 2. Analisa Kedudukan Muka Air Laut

\begin{tabular}{ccccccc}
\hline & Z0 & MSL & LLWL & HHWL & MLWL & MHWL \\
\hline Elevasi $(\mathrm{cm})$ & 62 & 62 & 13 & 126 & 39 & 89 \\
\hline
\end{tabular}

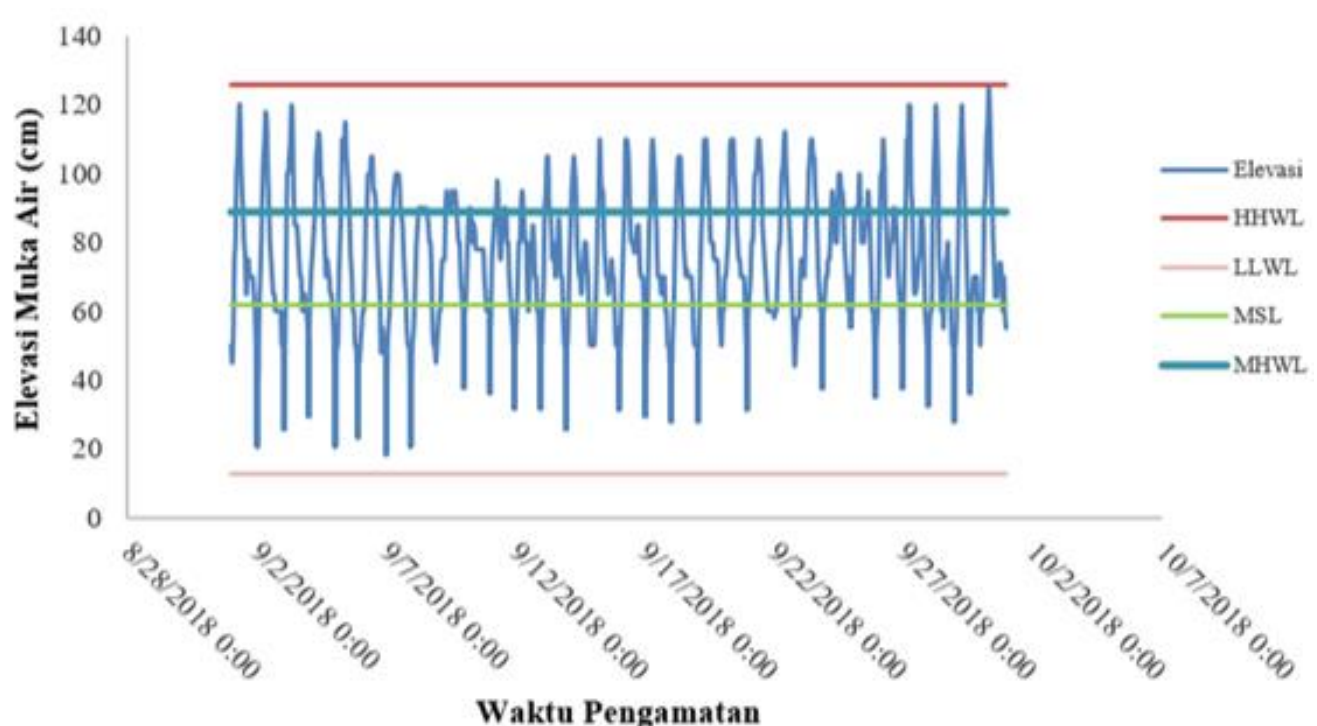

Gambar 1. Grafik Pasang Surut Pearairan Kaliboyo bulan September 2018 
Hasil pengukuran dan pengolahan data yang telah dilakukan didapatkan hasil nilai konsentrasi material padatan tersuspensi pada saat kondisi pasang menuju surut Tabel 1. Hasil yang diperoleh kemudian diinterpretasikan dalam bentuk peta sebaran secara horizontal dan vertikal pada saat kondisi pasang menuju surut pada kedalaman $0.2 \mathrm{~d}, 06 \mathrm{~d}$, dan $0.8 \mathrm{~d}$ yang dapat dilihat pada Gambar 2 sampai Gambar 5.

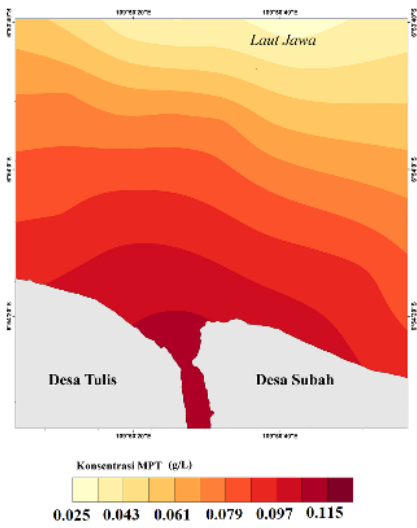

$0.2 \mathrm{~d}$

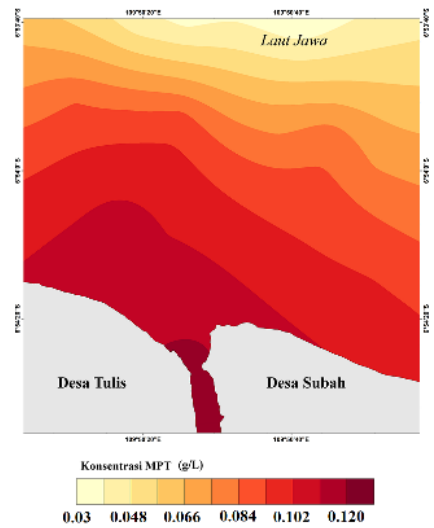

0.6d

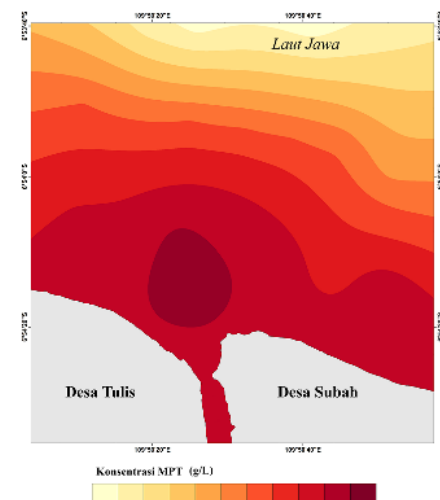

$\begin{array}{lllllll}0.035 & 0.053 & 0.071 & 0.089 & 0.107 & 0.125\end{array}$

$0.8 \mathrm{~d}$

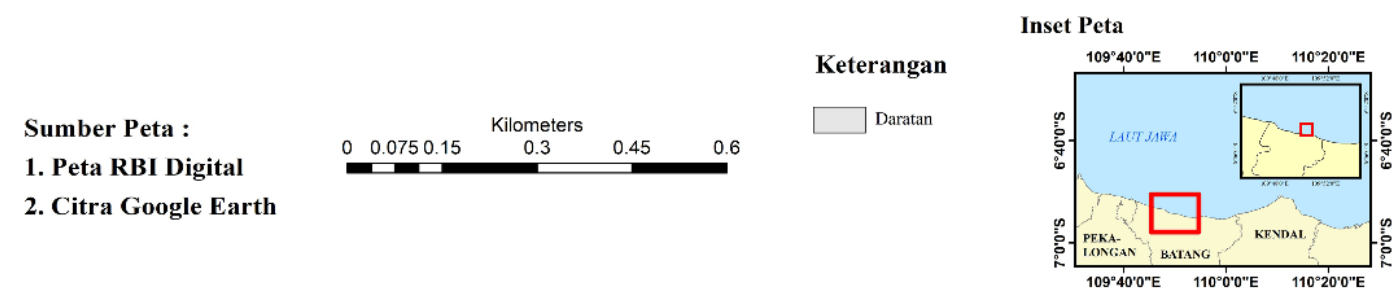

Gambar 2. Sebaran MPT Secara Horizontal saat Pasang Menuju Surut

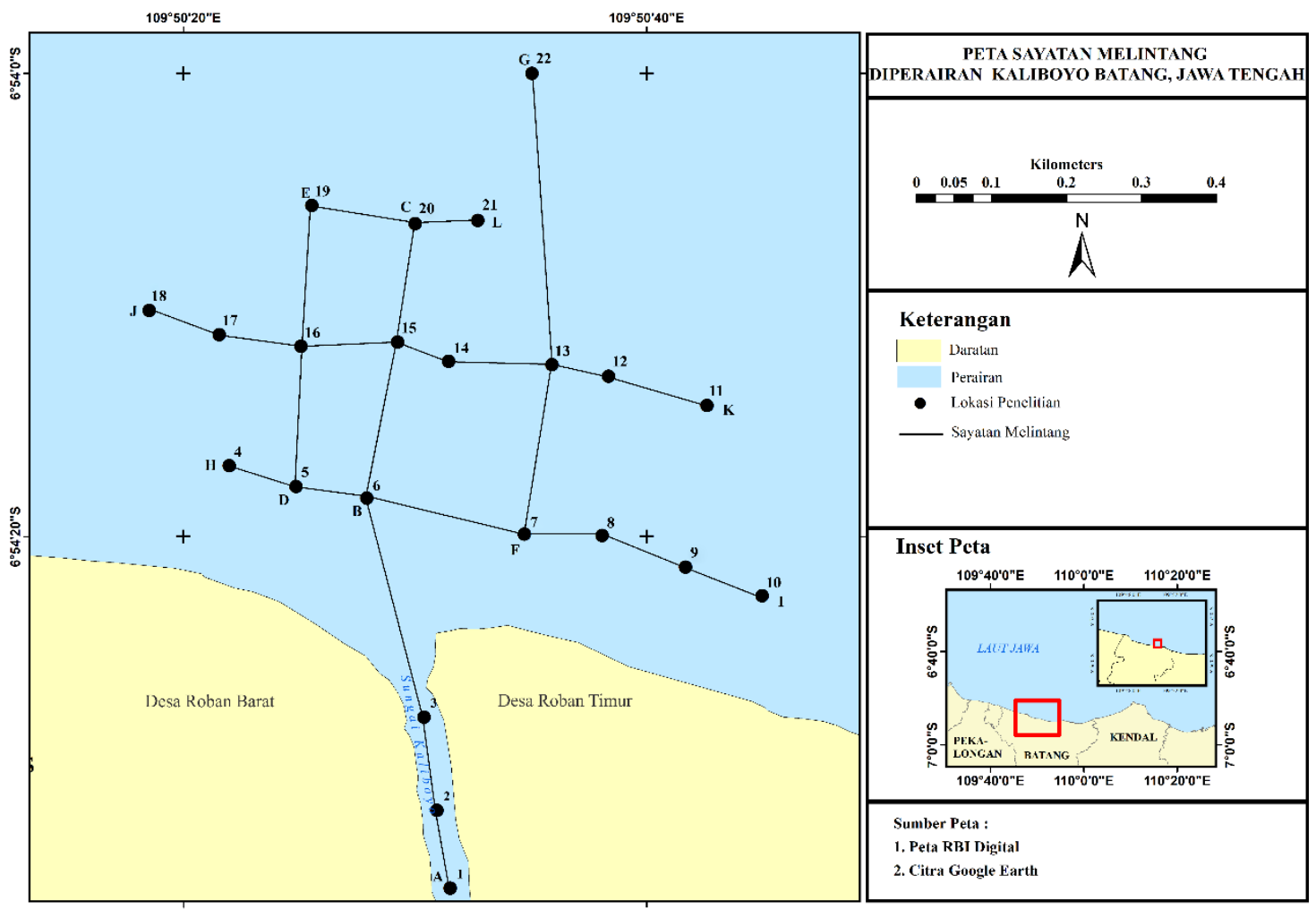

Gambar 3. Sayatan Melintang 

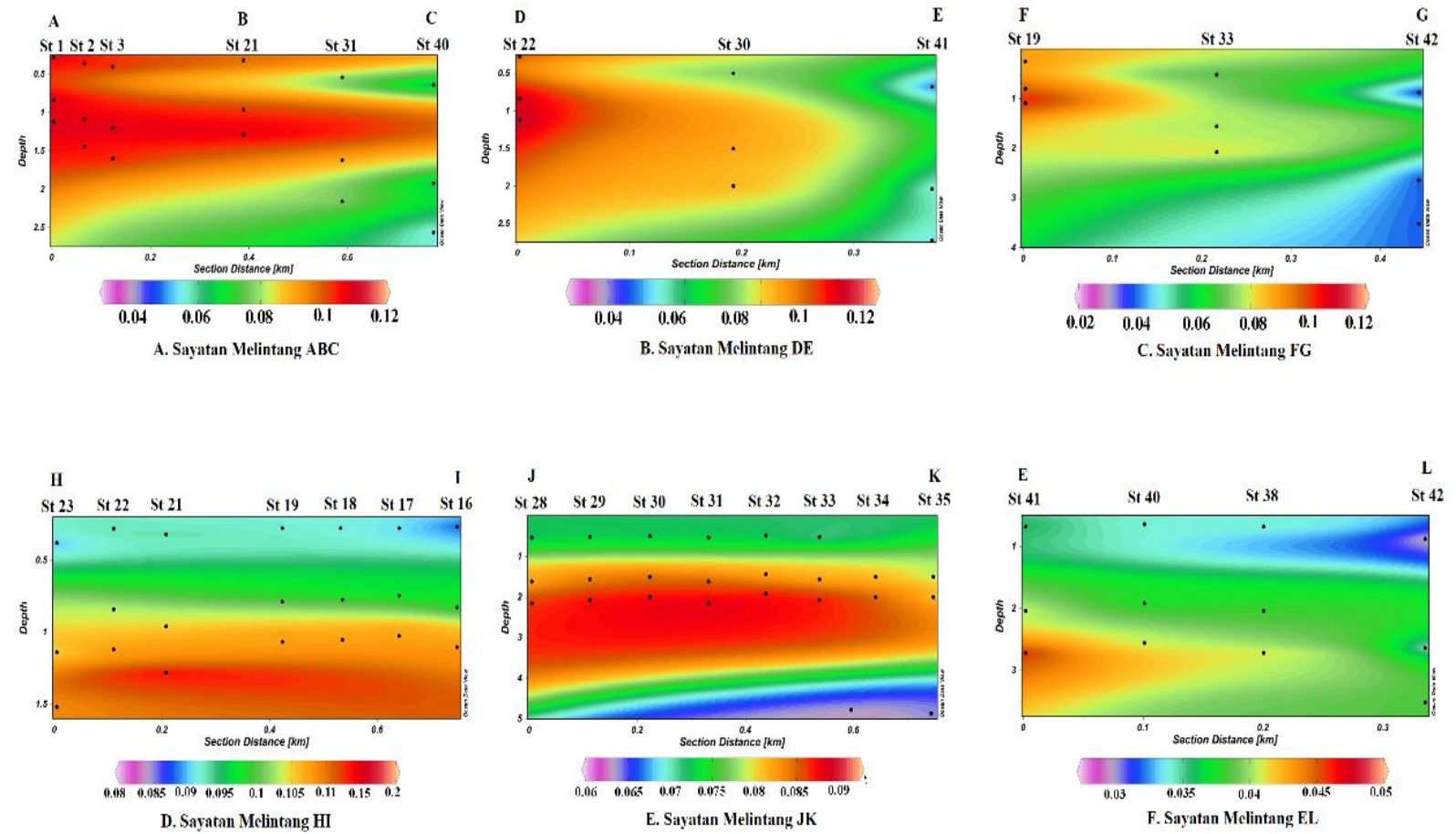

Gambar 4. Sebaran MPT Secara Vertikal saat Pasang Menuju Surut
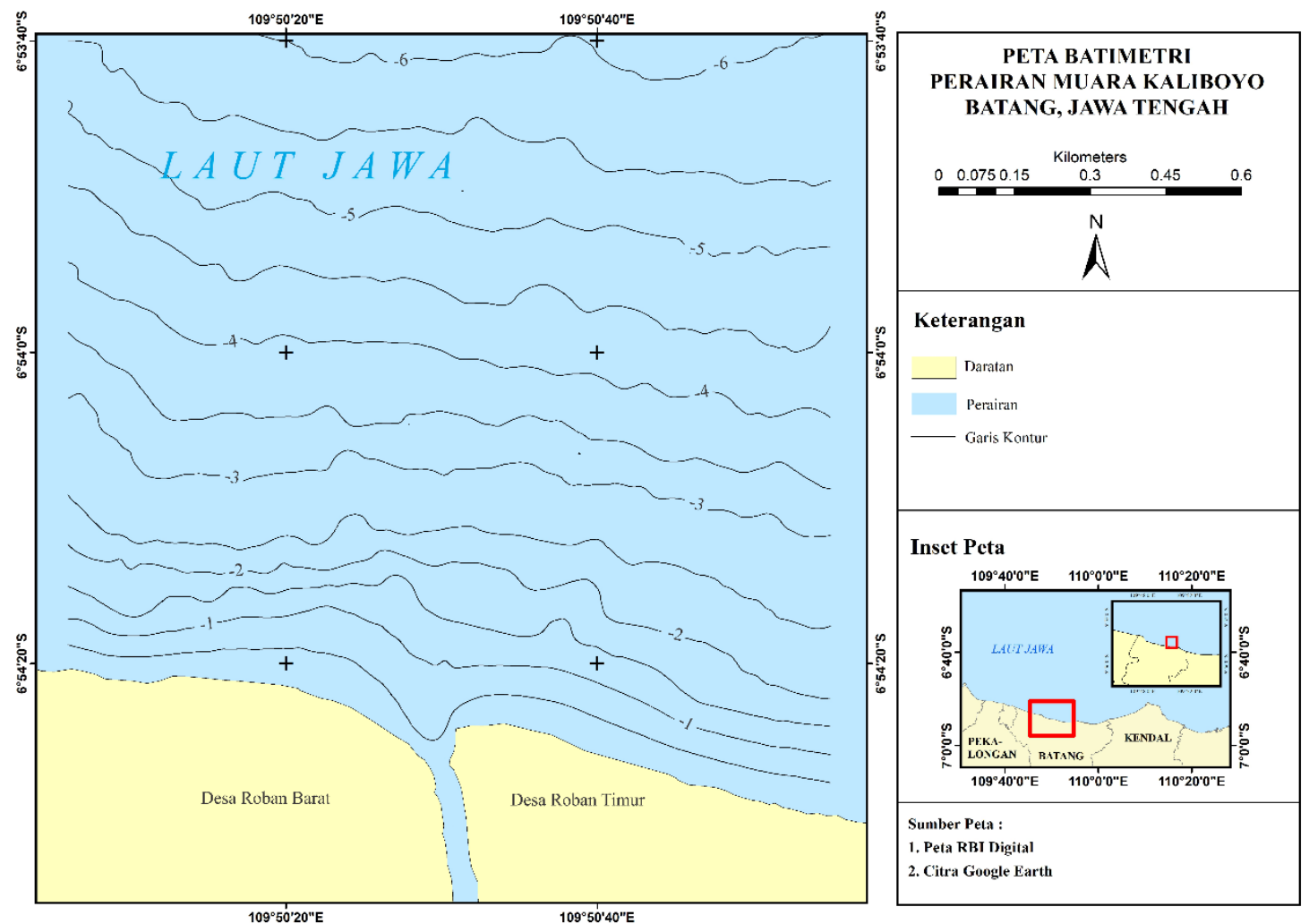

Gambar 5. Batimetri Perairan Kaliboyo

Pola sebaran material padatan tersuspensi di setiap layer kedalaman yaitu $0.2 \mathrm{~d}, 0.6 \mathrm{~d}$, dan $0.8 \mathrm{~d}$ (Gambar 2) menunjukan bahwa nilai konsentrasi tertinggi berada pada muara sungai dan daerah yang masih di pengaruhi oleh muara sungai, hal ini dikarenakan sumber material padatan tersuspensi ini berasal dari daratan yang masuk kedalam sungai, faktor oseanografi seperti arus dan pasang surut, serta akibat dari adanya aktivitas nelayan di muara Sungai Kaliboyo. Faktor 
tersebutlah yang menyebabkan terjadi penumpukan sedimen yang berada di daerah sekitar muara sungai yang menyebabkan terjadinya pendangkalan.

Pasang surut ini sangat berpengaruh terhadap sebaran dan nilai konsentrasi material padatan tersuspensi karena pada saat terjadinya pasang volume air akan bertambah yang mengakibatkan meningkatkan nilai konsentrasi material padatan tersuspensi dikarenakan saat terjadinya pasang terjadi pertemuan arus laut dan debit sungai di muara sungai sehingga menyebabkan terjadi peristiwa pengadukan sedimen yang cukup tinggi. Pada saat terjadinya pasang material padatan tersuspensi akan ikut terbawa dari laut yang kemudian diendapkan di sekitar muara sungai, sedangkan pada saat surut nilai konsentrasi material padatan tersuspensi akan lebih kecil dikarenakan kedudukan muka air laut lebih rendah dan cenderung lebih tenang.

Hasil pengukuran arus lapangan di Perairan Kaliboyo kecepatan arus minimum yaitu 0.0181 $\mathrm{m} / \mathrm{s}$ dan kecepatan arus maksimum $0.3906 \mathrm{~m} / \mathrm{s}$ dengan arah dari timur menuju dominan ke barat daya seperti yang ditunjukkan Gambar 7. Gambar 8 merupakan gambar yang menunjukkan arah dan kecepatan arus lapangan pada saat kondisi pasang menuju surut. Kemudian hasil pengolahan data arus menggunakan World Current dengan menggunakan vector plot dan scatter plot menunjukkan bahwa pengaruh arus yang dibangkitkan oleh pasang surut adalah dominan. Selanjutnya dapat dilihat pada Gambar 9.

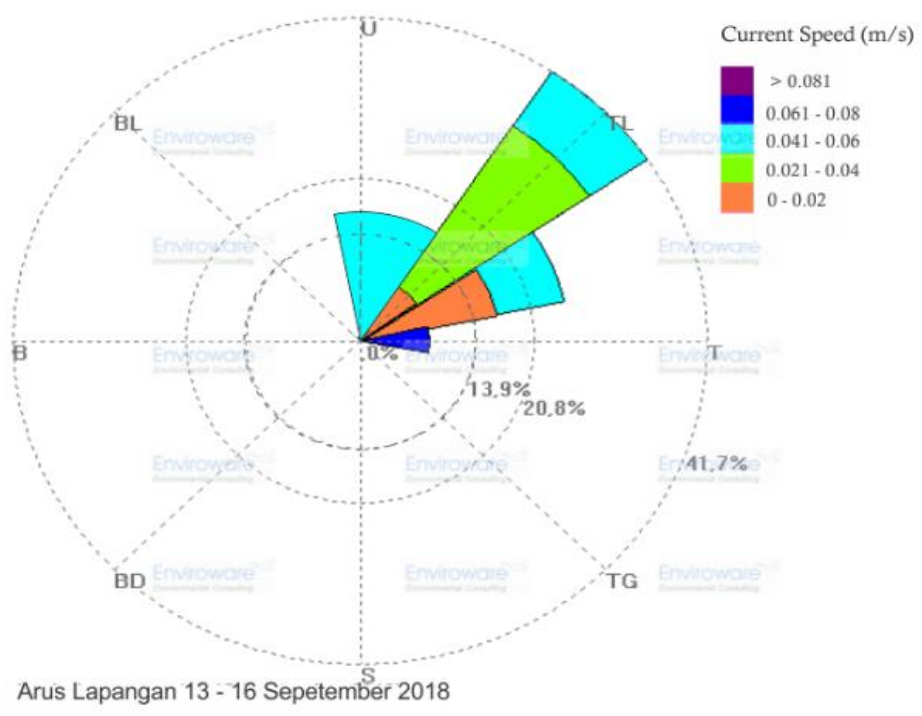

Gambar 7. Current Rose

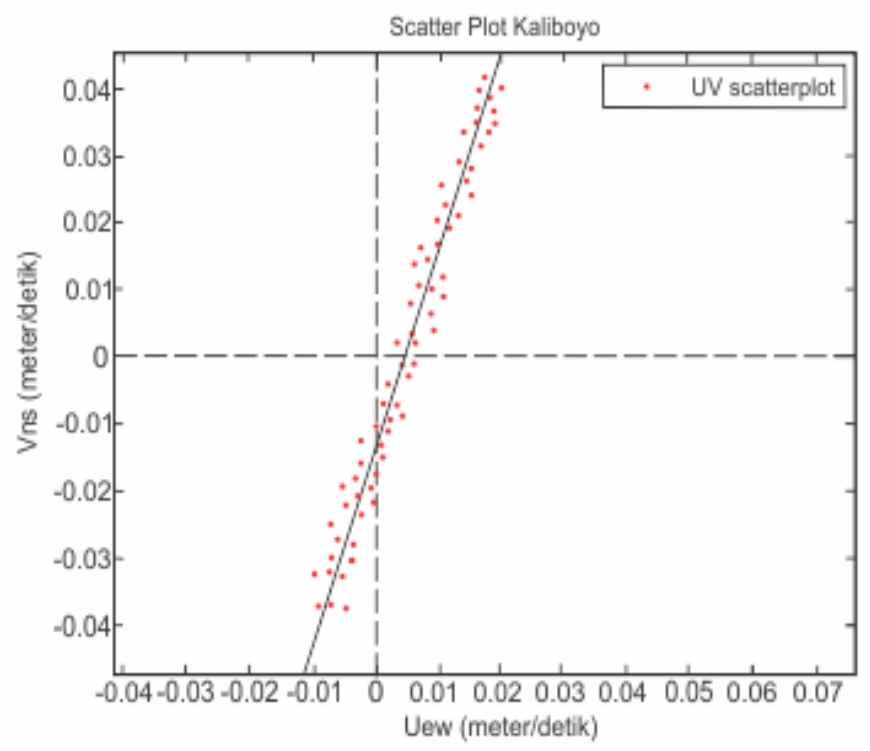

Gambar 8. Scatter Plot 


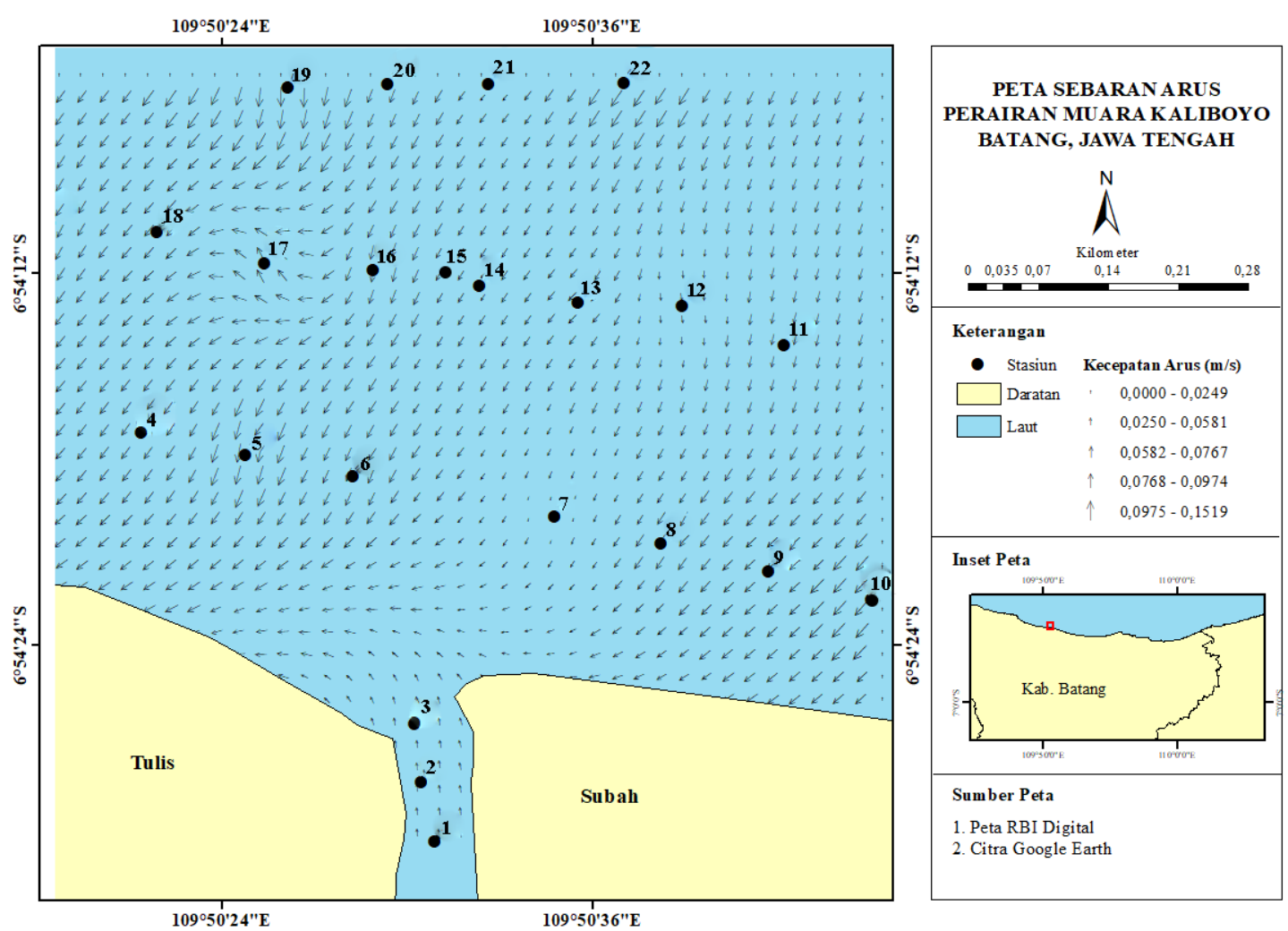

Gambar 9. Model Arus

Arus memiliki peran yang sangat besar dalam penyebaran sedimen dasar karena arus dapat mangaduk dan membawa sedimen menuju ke laut atau menuju ke daratan. Sedimen yang berukuran lebih kecil atau halus akan cenderung lebih mudah terangkut dan tersuspensi mengikuti kecepatan dan arah arus pada perairan tersebut. Menurut Triatmodjo (1999), dasar laut terdiri atas material - material yang mudah berpindah tempat atau bergerak, akibatnya arus dan gelombang akan mengerosi dan mengangkut sedimen. Arus laut akan menyebabkan terjadinya resuspensi sedimen sehingga menyebabkan nilai konsentrasi material padatan tersuspensi akan cenderung lebih tinggi di dekat daratan. Arah dan kecepatan arus akan sangat mempengaruhi pola persebaran dan nilai konsentrasi material padatan tersuspensi. Arus laut dengan kecepatan yang lebih besar akan dapat mengangkut sedimen dengan ukuran butir yang lebih besar. Pada daerah muara sungai merupakan tempat mengendapnya sedimen yang berasal dari daratan dan lautan, karena muara sungai daerah pertemuan antara daratan dan lautan, serta daerah yang sangat didominasi atau dipengaruhi oleh arus dan pasang surut.

Hasil pengolahan data juga menunjukkan bahwa arus yang mendominasi perairan Kaliboyo adalah arus pasang surut. Arus pasang surut mempunyai sifat bergerak dengan arah yang saling bertolak belakang atau bi-directional. Sebaran material padatan tersuspensi perairan Kaliboyo saat pasang menuju surut sesuai atau mengikuti arah arus dominan pada saat pengambilan data. Hal ini sangat relevan dengan pernyataan Poerbandono dan Eka (2005) yang menyebutkan bahwa, kecepatan dan arah arus dapat digunakan sebagai acuan untuk memperkirakan besar kecilnya energi yang dibutuhkan untuk memindahkan material sedimen dari suatu tempat ke tempat yang lainnya.

\section{KESIMPULAN}

Mengingat penelitian ini hanya dilakukan pada saat musim peralihan 2 dan hanya pada saat pasang menuju surut, maka sangat diperlukan penelitian yang berkesinambungan diperairan Kaliboyo pada musim yang lain dan pada saat kondisi pasang menuju surut dan surut menuju pasang, serta perlu dilakukannya pengkajian pola arus dengan permodelan guna permasalahan dapat ditanggulangi lebih dini. 


\section{UCAPAN TERIMAKASIH}

Artikel ini adalah bagian dari Skripsi yang berjudul "Pengaruh Arus Pasang Surut Terhadap Distribusi Material Padatan Tersuspensi Di Perairan Kaliboyo" sebagai syarat memperoleh gelar Sarjana Strata Satu Program Studi Osenografi Fakultas Perikanan dan Ilmu Kelautan, Universitas Diponegoro.

\section{DAFTAR PUSTAKA}

Alaerts, G. \& Santika, S.S. 1987. Metoda Penelitian Air. Usaha Nasional, Surabaya.

Fadilah, S. \& Dwi, P. S. 2014. Menentukan Tipe Pasang Surut dan Muka Air Rencana Perairan Laut Kabupaten Bengkulu Tengah Menggunakan Metode Admiralty. Maspari Journal, 6(1):112

Goerge, M,S., Bertino, L., \& Johannessen, O.M. 2010. Validation of a Hybrid Coordinate Ocean Model for the Indian Ocean. Journal of Operational Oceanography,3(2):12-18

Morissan. 2017. Metode Penelitian Survei. Jakarta: Kencana.

Mulyanto, H.R. 2007. Sungai, Fungsi dan Sifat-sifatnya. Graha Ilmu. Yogyakarta.

Poerbandono \& Djunarsjah, E. 2005. Survei Hidrografi. Bandung: Refika Aditama.

Qhomariyah, L \& Yuwono. 2016. Analisa Hubungan Antara Pasang Surut Air Laut Dengan Sedimentasi Yang Terbentuk. Jurnal Teknik ITS 5(1):1-3.

Rifardi. 2012. Ekologi Sedimen Laut Modern Edisi Revisi. Pekanbaru. UNRI Press.

Satriadi, A. \& Widada, S. 2004. Distribusi Muatan Padatan Tersuspensi di Muara Sungai Bodri, Kabupaten Kendal. IImu Kelautan, 9(1):101-07.

Triatmodjo, B. 1999. Tehnik Pantai.Yogyakarta, Beta Offset.

Yusuf, M. 2017. Metode Penelitian (Kuantitatif, Kualitatif, \& Penelitian Gabungan). Jakarta: Kencana 